\title{
Reuna
}

\section{PERCEPTIONS OF BRAZIL'S COUNTRY IMAGE AFTER THE BRIC'S RUSH}

\section{A IMAGEM DE PAÍS DO BRASIL APÓS A CORRIDA DOS BRICs}

\author{
http://dx.doi.org/10.21714/2179-8834/2018v23n3p54-70
}

\author{
Ivanete Schneider Hahn \\ Universidade Federal de Santa Maria (UFSM), Brasil. \\ Universidade Alto Vale do Rio do Peixe (UNIARP), Brasil. \\ E-mail: ivischneider@hotmail.com \\ Flavia Luciane Scherer \\ Universidade Federal de Santa Maria (UFSM), Brasil. \\ E-mail: fscherer@smail.ufsm.br
}

\section{Clandia Maffini Gomes}

Universidade Federal de Santa Maria (UFSM), Brasil.

E-mail: clandia@smail.ufsm.br

\author{
Ana Paula Perlin \\ Universidade Federal de Santa Maria (UFSM), Brasil. \\ E-mail: anapaula.perlin@yahoo.com.br \\ Maria Carolina Serpa Fagundes Oliveira \\ Universidade Federal de Santa Maria (UFSM), Brasil. \\ E-mail: mc.sfagundes@gmail.com
}

Submissão: 31 Mai. 2017 Publicação: 25 Fev. 2019. Sistema de avaliação: Double blind review. Centro Universitário UNA, Belo Horizonte - MG, Brasil. Editor geral: Prof. Dr. Gustavo Quiroga Souki

Este artigo encontra-se disponível nos seguintes endereços eletrônicos:

http://revistas.una.br/index.php/reuna/article/view/932

http://dx.doi.org/10.21714/2179-8834/2018v23n3p54-70

\section{ABSTRACT}

This paper reports an empirical study of Brazil's country image. The purpose is to analyze (1) the existing perceptions of Brazil after the BRIC's rush, (2) if there are differences between groups and (3) why such differences exist. Two studies were performed with people from foreign countries. Findings suggest that the image of Brazilian products cannot be considered a competitive advantage (except for typical products such as coffee, cachaça, etc.). It was also found that foreigners who have visited Brazil or with higher levels of educational attainment create an emotional bond and have a more positive image of Brazil. We concluded that researchers and marketing managers should not ignore the importance of country image or consider the image of Brazil as non-relevant to product acceptance in the international market.

Keywords: Country image. COO effect. Marketing. International Marketing. 


\section{RESUMO}

Este artigo relata um estudo empírico sobre a imagem de país do Brasil. Assim, destinou-se a investigar (1) quais são as percepções que os estrangeiros possuem do Brasil após a corrida dos BRIC; (2) se há diferenças nas percepções entre grupos (divididos pelas características sociodemográficas); e (3) por que tais diferenças existem? Dois estudos foram conduzidos junto à estrangeiros (não brasileiros). Os resultados permitem inferir que: a imagem do Brasil em produtos não pode ser considerada uma vantagem competitiva (exceto produtos típicos como café, cachaça...). Verificou-se ainda que estrangeiros que já visitaram o Brasil, ou com mais escolaridade criam um vínculo emocional e possuem uma imagem mais positiva do Brasil do que os demais. Conclui-se que não convém aos pesquisadores e gestores de marketing ignorar ou descartar a imagem do Brasil como não relevante na aceitação dos produtos no mercado internacional.

Palavras-chave: Imagem de país. Efeito país-de-origem. Marketing. Marketing internacional.

\section{Introduction}

Not long ago, Brazil, Russia, India and China attracted jealous glances in the international arena. Forecasts showed the emergence of these countries so that they would no longer depend on developed countries for their economic growth. However, many signs from the market have shown that this conclusion may have been hasty and that the race of emerging countries known as BRIC came to end (MONTEALEGRE, 2013), what happened on last November (BLOOMBERG, 2015). For the authors, one of the main signs from the market that suggests the end of the BRIC's race is the growth deceleration in these countries because of the European crisis and the slow growth of the US economy and problems in the management of BRICs, which increases distrust of investors. This does not mean that these markets have exhausted their potential for growth, but the golden age is over, and new countries are becoming the preferred choice of investors.

However, the decade of the fast-growing BRIC countries projected their image in the international arena. The long-time exposure of these countries on TV news shows, newspapers, magazines, meetings and international events may have contributed to building their country image, which influences the country-of-origin effect of products traded internationally. Thus, this article aims to answer the following research questions: (1) What are the existing perceptions about Brazil after the BRIC's rush? (2) Are there any differences between groups? (3) Why do such differences exist?

Clearly, when a company decides to act in the international market, it should be prepared to be faced with stereotypical attitudes toward products and services that can both foster and hinder the development and implementation of marketing efforts in the destination country (GUILHOTO, 2001). For most authors, Brazil still has a negative image, a situation that seems to be improving over the years. List of some evidence of changes in the view of foreigners, where even if subtly, Brazil started to be a key market for business. Improving a country's image can bring benefits such as increased product 
exports and a greater number of tourists from other countries (MORGAN et al., 2002; MARIUTTI; GIRALDI, 2012).

In addition, country image, according to Mariutti and Giraldi (2012), is an area of study that is gaining interest among researchers internationally. It is highly relevant to business growth and strongly related to a nation's social, cultural and economic positioning. Thus, this study aims to broaden the understanding of the stereotypical beliefs of foreigners about Brazilian organizations - their products and their respective marketing, the Brazilian people, Brazilian arts - and about a broader and political issue, which relates to the image of Brazil abroad.

In order to meet the objectives, this paper have five sections. The first one intended to contextualize the topic under study. The second section reviews the main literature that supports the issues under analysis. The third chapter presents the methodology of the study, followed by the results and discussion. Finally, the last section presents the final remarks, limitations of the study and suggestions for future research

\section{Theoretical Background}

This section present the theoretical background about The BRIC's rush, country image and the image of Brazil and its products.

\subsection{The bric's rush}

When launched in 2001, the concept of BRIC was supported by a forecast that, unlike so many others previously suggested, indicated that the economies of the four countries, considered as emerging, would grow and their share of the world output would become more expressive, thus attracting foreign investment (FONSECA Jr., 2011). Such a situation occurred when O'Neill (2001) pointed Brazil, Russia, India and China as emerging economies, which over the years could become the largest economies in the world, because of their potential to sustain the global economy in the coming decades. In 2006, the concept has given rise to a group per se, incorporated into the foreign policy of these countries.

Based on the newly created nomenclature and driven by the growth rate of four emerging economies, as well as on their potential to attract investments, various research studies and surveys have been conducted ever since on this "novelty" called BRIC (ARMIJO, 2007; BARBÉ, 2010; BAUMANN, 2010; HURRELL 2006; IKENBERRY; WRIGHT, 2008; NARLIKAR, 2013; NOGUEIRA, 2012; THORSTENSEN, 2012). The member countries of BRIC account for an economic development model characterized by a strong growth rate and a great capacity to compete in a globalized world (VIVERO; MATEOS, 2010).

Based on joint efforts that demonstrate the involvement of the four countries, the BRIC classification adds something beyond the label of emerging countries. According to Fonseca Jr. (2012), it immediately adds a "brand" through a new expression that distinguishes these countries from other emerging countries. In a world where information is constantly produced and conveyed, can foster changes and is deemed as essential, brand management is crucial to expose the individual importance of each country to the group and the global context. As advocated by Fonseca Jr. 
(2012), China is one of the engines of the world economy. Russia is important in terms of safety, given the size of its nuclear arsenal and relevance in the energy market. India is relevant demographically and has regional influence, in addition to being the largest "real" democracy in the world. Finally, Brazil is a key player in negotiations on sustainable development and trade.

From this perspective, considering that the concept of the race of emerging countries, known as BRIC, seems to have come to end (MONTEALEGRE, 2013), the influence of these years of exposure and growth on Brazil's image is worth of analysis.

\subsection{Country Image}

A country's image is developed by the combination of several elements that generate preconceptions, which may influence the products manufactured in a particular country (MARIUTTI; GIRALDI, 2012). When consumers make purchasing decisions, they seldom have access to all the information required; thus, their evaluations and decisions are influenced by aspects of the product that they can observe - including the country of origin - and this provides consumers with the basis for defining the level of quality of the product they wish to purchase. (GUILHOTO, 2001)

Consumer perception of a country's image helps shape stereotypes relative to these beliefs with respect to their landscape, culture and economy. These beliefs form a complex mental structure, which allows consumers to make an initial assessment of a country's performance, and conclusions about the attributes of the products (VERLEGH et al., 1999). The authors understand the stereotypes of a country based on three dimensions: social and economic structure, culture and geography.

The socioeconomic dimension is the pattern of interrelationships between the elements of a social system that can be represented by parameters such as development, wealth, political power, industrialization and prestige. By contrast, the geographical dimension is understood by means of perceptions about climate, landscape and environmental aspects. Finally, the cultural dimension is defined as the ways in which members of a group are different from members of other groups (VERLEGH et al., 1999). Guilhoto (2001) emphasized that culture includes values and patterns of behavior involving groups of people, and they help to distinguish one group from another, thus affecting both the way people see a situation and the way in which these observations influence their behavior. Culture is represented by elements such as religion, education level, government, family and language.

A country's image influences consumer assessment of products from a country, causing the so-called "country-of-origin effect" (COO) (GIRALDI; IKEDA, 2009). Therefore, the country-of-origin effect may be considered as an intangible barrier to entry into new markets or countries, in the form of consumers' negative views of imported products (AGBONIFOH; ELIMIMIAN, 1999; WANG; LAMB, 1983), that is, people have stereotyped evaluations of other people and countries and, thus, the products manufactured in these countries (BALABANIS et al., 1999). Limiting factors of the country-of-origin effect include consumer characteristics that, according to Giraldi and Tornavoi (2005), can be: age, sex, education and conservatism, brand 
familiarity, fluency in the country's language, need for cognition, degree of involvement with culture, motivation and number of clues about the product.

Consumers' stereotypes about countries and people can transcend the assessment of brands or specific products and determine purchase intentions and people's behavior (HAN, 1989; JAFFE; NEBENZHAL, 2006; JOHANSSON et al., 1985; ULGADO; LEE, 1998; WHITE; CUNDIFF, 1978).

\subsection{Image of Brazil and its products}

After the theory about country image is explained, the issue must be contextualized from the perspective of studies conducted on Brazil's image. Overall, Brazil's products are not associated with high quality. For example, the study of Gaedke (1973) showed that food, textile and electronic goods manufactured in developing countries were perceived as inferior to American products.

Ghoshal and Tanure (2004) argued that Brazil's image abroad is still associated with an emerging country undergoing economic, political and social hardship; consequently, products with low prices and low profit. Other studies (ALMEIDA; DROUVOT, 2009; GIRALDI; CARVALHO, 2006; GIRALDI; NETO, 2008; PESSOA; AYROSA, 2010) seem to confirm this aspect, where the results showed an unfavorable and negative image of Brazil. These results are important sources of information for managers of companies whose aim is internationalization.

\section{Materials and Methods}

The objective of this paper is to verify the existing perceptions about Brazil after the BRIC's rush. Another objective was to study if there are any differences between groups and why do such differences exist. Thus, two studies were conducted - the first was a cross-sectional survey, and the second sought to explore the theme, through interviews - as described below.

\subsection{Study 1}

The methodological procedures used to collect answers to meet the objectives of this study followed the steps proposed by Hair et al. (2005) for the cross-sectional survey method.

\section{Measures}

In the instrument, the scales were adapted from Brazilian studies conducted by Ayroza (1998), Giraldi (2005) and Nebenzahl et al. (2006). Thus, the data collection instrument contained two parts. The first was comprised of the characteristics of respondents (gender, age, country of origin and academic degree). The second part contained 28 observable variables, divided into five latent variables: general aspects of Brazil: people and products (14 observable variables), emotional response (3 observable variables), arts-related attitudes (3 observable variables), marketing 
aspects (4 observable variables) and importance in the global scenario (4 observable variables).

The measurement scale consisted of a Likert scale, where respondents attributed degrees of agreement from 1 (strongly disagree) to 5 (strongly agree).

\section{Research sample}

To perform this research, the study population consisted of foreigners from countries that are the main trade partners of Brazilian export companies and have economic relations with them. With the aid of the researchers' networks, an invitation was sent through digital media (email, Facebook, closed groups) containing a link to fill out the online survey.

In total 255 questionnaires were returned. This sample, however, cannot be considered as probabilistic, given that the probability of inclusion of each member of the population in the sample is not known nor equivalent (MALHOTRA, 2006).

\section{Data analysis}

The collected data were analyzed using the software SPSS Statistics 21, through univariate and multivariate analyses. The next steps were followed: (1) preparation of the data matrix (2) descriptive analysis of the sample; and (3) multivariate analysis to determine the underlying structure of the dataset from the survey.

\section{Preparation of the data matrix}

First, we tested the statistical assumptions on multivariate applications. Thus, the data collected passed through the following treatments: identification of outliers, missing values, distribution of data, multicollinearity, homoscedasticity and dimensionality.

A simple frequency distribution of the missing data showed that there were no missing data. By calculating Mahalanobis Distance (level of significance 0,001), 10 questionnaires were excluded because they were outliers. Analysis of normality was performed by the Kolmogorov-Smirnov test, and no abnormal variables were observed. A collinearity test was applied by the analysis of values of tolerance and the variance inflation factor (VIF), and none of the variables presented a high level of multiple associations. A Levene's test, through ANOVA, checked the equality of variances in the samples (homogeneity of variance $-p>0.01$ ). None of the variables showed heteroscedasticity.

The one-dimensionality of the construct was verified through exploratory factor analysis (EFA), maximum likelihood extraction and Oblimin rotation with 28 country image indicators, divided into five latent variables. Three observable variables of the dimension General aspects of Brazil: people and products were excluded because they had very low commonalities and cross-loadings above 0.40 . 


\section{Sample Characteristics}

The sample used in this study was comprised of 245 questionnaires. There were respondents from 30 countries and the main ones were Portugal (38.45\%), United States (7.8\%), Paraguay (14.1\%) Germany (5.5\%), Mexico (5.1\%), Belgium $(4.7 \%)$, Canada (3.5\%), England (3.1\%), and Argentina (2.4\%).

The average age of respondents was 30 years old, ranging between 17 and 66 years old. The sample consisted of $53.7 \%$ women and $46.3 \%$ men. With regard to marital status, there is a large concentration of single respondents $(66.7 \%)$ while $28.6 \%$ of respondents are married. Moreover, $57.3 \%$ of respondents have an undergraduate degree, $28.6 \%$ have a graduate degree, and $14.1 \%$ have no academic degree.

\subsection{Study 2}

The qualitative step was performed because the quantitative step did not provide large inferences about the motives of these scores and, thus, there was the need to explore the nature of the phenomenon under analysis (Flick, 2009).

This step was implemented by applying interviews with questions drawn up based on observable variables proposed by Ayroza (1998), Giraldi (2005) and Nebenzahl et al. (2006), with the same standards used in Study 1. The script was composed of 18 open questions, available in versions in Portuguese, English and Spanish.

For this step, the delimitation of the sample is characterized by its nonprobabilistic, intentional and convenient nature, where researchers select the elements while admitting that they can somehow represent the universe (Gil, 2010). Therefore, interviews were conducted with 24 people from 12 countries, namely: Colombia, Ireland, Italy, Spain, Peru, Venezuela, France, Germany, Canada, Mexico, Argentina and Uruguay. The interviews took place through online tools for voice and video calls.

For data analysis, the material was transcribed verbatim. The collected data have a hybrid format; they were grouped by words, and content analysis was used as an examination technique.

\section{Sample characteristics}

A total of 24 people was interviewed from 12 countries, namely: Colombia (4), Ireland (2), Italy (2), Spain (2) Peru (1), Venezuela (1), France (1), Germany (6), Canada (2), Mexico (1) Argentina (1) and Uruguay (1). Respondents are 29 years old on average (between 19 and 46 years) and they are mostly women (18 in total).

Out of the 24 respondents, 16 have an undergraduate degree, 5 hold a graduate degree, and 3 have no academic degree. Among the respondents, 17 have already visited Brazil, while others indicated that they gather information about the country through various media and their Brazilian friends. 


\section{Results}

This section presents the results based on the research purposes that support the empirical studies. Firstly, we investigated the existing perceptions about Brazil after the BRIC's rush. Additionally, we checked if there are any differences between groups and why such differences exist.

\subsection{Existing perceptions about Brazil after the BRIC's rush}

Through analysis of the dimensions of Brazil's image (Table 1), it was found that the sample had a positive emotional response towards Brazil. It was also found that the respondents believe in the quality of Brazilian art, but they consider the quality of products to be average; they also think that there is little investment in marketing for Brazilian products.

Table 1: Analysis of country image dimensions

\begin{tabular}{ccccc}
\hline Latent variables & $\begin{array}{c}\text { Number of } \\
\text { observable } \\
\text { variables }\end{array}$ & Mean & $\begin{array}{c}\text { Standard } \\
\text { deviation }\end{array}$ & Reliability \\
\hline $\begin{array}{c}\text { General aspects of Brazil: } \\
\text { people and products }\end{array}$ & 11 & 3.25 & 0.439 & 0.877 \\
Emotional response & 3 & 3.82 & 0.707 & 0.780 \\
Arts-related attitudes & 3 & 3.71 & 0.784 & 0.869 \\
Marketing aspects & 4 & 2.92 & 0.747 & 0.824 \\
Importance in the global & 4 & 3.49 & 0.670 & 0.810 \\
\hline scenario & & & & \\
\hline
\end{tabular}

Source: Authors' calculations based on survey data

${ }^{*}$ Reliability estimated using Cronbach's alpha

Particularly, Brazilian products seen as trustworthy (3.45) on average and companies have achieved average production standards (3.53) and are creative. However, it appears that the products are not seen as environmentally friendly (2.94), and they do not have a positive technical evaluation.

This analysis was corroborated in the interviews, where it was found that Brazil does not produce high-quality material, but such material can be recognized worldwide as having average quality. As far as this topic is concerned, foreigners who have visited Brazil have a different perception from those who only know the country through the media, that is, people who have never visited Brazil recognize products as having average or low quality. Those who have been to Brazil stressed that some products may be recognized as high-quality as compared to the situation in their countries of origin, as in the case of fruits, vegetables and meat. They also mentioned that they found products in Brazil that do not exist in other countries. 
However, when such quality is compared to prices charged, it was found that the high cost of products was commonly perceived by respondents as not consistent with the average or low quality of such products.

Respondents believe that Brazilian products are reliable, but they are not prestigious in the international market. In other words, they cannot perceive Brazil as a standout in any sector, as is France with cosmetics and perfumes, Germany with the automotive industry and the United States with high-tech products. So, when asked which product is the most closely associated with the image of Brazil, some product categories and brands were mentioned, such as food products (meat, fruits, soy, rice, beans), drinks (coffee, beer and cachaça), footwear (Havaianas flip-flops) and cosmetics (Natura and Novex). Except for the aircraft manufacturer Embraer, they do not see Brazil as a country that develops high technology.

With respect to the people, respondents from the sample believe that the Brazilian people are trustworthy (3.47) and hard-working (3.44), but generally violent. This result was confirmed by the interviews; foreign respondents stated that among emerging countries, Brazil is best remembered by violence. It can thus be inferred that even if the country has grown and expanded its markets, and sought to become a major player in the global economic arena, violence is still strongly characteristic of the nation. In the respondents' opinion, violence is caused by social inequality and poor access to education, which leads to social problems, poverty and drug use.

As for the emotional response of foreigners to Brazil, the respondents like Brazil (4.19) and sympathize with Brazil (4.02). In the interviews, the understanding of the emotional response of foreigners to Brazil is divided into two subcategories: (1) country-related aspects and (2) national companies operating in foreign markets.

When understood in its broadest form, i.e., as a nation, Brazil produces a very positive image on the minds of people from other countries, which confirms the results of Study 1. This image is mainly portrayed in Brazil's natural beauty and Brazilians' hospitality, in addition to more traditional aspects that have earned the country worldwide recognition, such as sports and festive celebrations. Over time, these features have highlighted the country in the global arena, although they have strengthened the country's image as "decorative, but not helpful" (MARIUTTI; GIRALDI, 2012).

When the analysis is more closely associated with emotional response to Brazilian companies, it is noteworthy that over the past decades, companies have been earning importance and prominence abroad. According to Rocha and Melo (2011), many companies are earning importance and international visibility, e.g., Gerdau, Vale, Marcopolo, JBS-Friboi, Marfrig and Weg. Therefore, respondents showed that they increasingly trust Brazilian companies, especially by highlighting Brazil's position in the global economy, a reputation that is assigned to companies trading internationally.

However, some of the respondents said that although Brazil had grown in economic terms and had gained greater respect from international agencies, they still found it hard to believe in Brazilian organizations, with possible exceptions made only for companies whose brands are consolidated in foreign markets, such as Natura. This shows that further efforts are required of organizations about their products and ways to market them in order to foster a positive country image and gradually eliminate negative aspects. 
As for arts-related attitudes, both studies confirmed that Brazil is acknowledged in the international art scene (3.69). These results appear to result in a positive emotional response, associated with national characteristics of festivities and artists. Therefore, regard artistic skills, Brazil is perceived as a country that stands out internationally for their creativity, especially through music, where Bossa Nova and Samba are particularly famous.

Nevertheless, when creativity is considered for product design, foreigners do not recognize Brazilian products as innovative and creative. This fact is confirmed by the analyses of Kotler and Gertner (2004), which linked the image of Brazil to carnival, natural beauty, soccer and music, or to people, such as Pele, Gisele Bündchen, Ronaldo and Zico. These predicates are also defined by Mariutti and Giraldi (2012) as "decorative, but not useful" in the competition by Brazilian companies in the global arena.

Marketing aspects, primarily related to Brazilian products, reflect the small investment made by Brazilian companies, and the sample believes that the products are not widely available nor are easily found around the world. These analyses are evidenced in both studies. Respondents argued that there is little advertising of Brazilian products, mostly on the Internet rather than in mass media. However, they highlighted the high creativity of advertisements that address natural aspects of Brazil, e.g., animals, forests and beaches, besides the use of images of carnival and women.

For the respondents of this study, it is not easy to find Brazilian products in their countries, and this is a recurrent situation both in Europe and in the Americas. Only products regarded as traditional in Brazil are found more easily (for example, Havaianas flip-flops, coffee, beans and cachaça). Yet, respondents suggested that these products hardly explore the 'made in Brazil' label, i.e., their packaging does not highlight the country of origin.

Finally, respondents from the sample believe that Brazil is respected in the world economy (3.69), and it is considered as important in the international political arena (3.55); such importance is passed on to companies - which have become respected internationally (3.35).

Considering the BRIC context and exposure of emerging economies in the world scenario over the past few years, Brazil has increased its involvement in cooperative regulation of international economic relations, exerting greater influence on decisionmaking mechanisms (Almeida, 2008). This exposure and recognition of Brazil as an emerging country, in the view of respondents, boosted the prestige of Brazil as a major player in the global market. According to respondents, the country can be considered one of the largest economies in the world, and it is highlighted as the most powerful in Latin America.

However, the results suggest that even though it is the 7th largest economy in the world, Brazil still lags behind countries such as the US and China - not only with regard to economic aspects, but also in general aspects of growth. According to the respondents, although the country is facing unfavorable times economically, it can resume growth, and they point the exploitation of natural resources as a way to boost the industry and, consequently, the economy. Another issue identified as a problem, which hurts the image of Brazil, is the corruption that occurs in the political context and in major Brazilian companies. 
Still, Almeida and Drouvot (2009) pointed out the fact that developed countries, on average, make a better assessment of the image of underdeveloped countries. Studies indicated that countries like Japan, Germany and the United States have the most favorable image, while emerging countries such as Mexico, Thailand, Taiwan are countries considered to have an unfavorable image.

As for Brazilian companies operating in foreign markets, there is weak recognition and respect in the world economy, because they are little influential in the international market. The most consolidated companies in the foreign market, which were cited in the survey, are Ambev and Natura.

In general, the image of Brazilian products cannot be considered a competitive advantage (except for typical products such as coffee, cachaça, etc.); these results corroborate those found by Giraldi (2005). Brazilian companies operating in a country where its image is unfavorable, should adopt strategies to minimize such negative impact.

\subsection{Differences between groups}

As a complement, this paper sought to check whether there were different analyses and views between the groups, by dividing them into personal characteristics (such as gender, marital status and education) and how respondents learned about Brazil. In this sense, an analysis was made while dividing the sample into two groups. The first group has visited Brazil and the second group watched or read news about Brazil in the various media and or have Brazilian friends (Table 2). The results demonstrate that emotional response shows significant difference between the two groups; those who have visited Brazil, in general, make better assessments of all country image aspects. This result is confirmed by Study 2 .

\section{Table 2: Difference between groups in country image evaluation}

\begin{tabular}{|c|c|c|c|c|c|}
\hline \multirow[t]{2}{*}{ Latent variables } & \multicolumn{2}{|c|}{ Have visited Brazil } & \multicolumn{2}{|c|}{$\begin{array}{c}\text { Learned about } \\
\text { Brazil through the } \\
\text { media or Brazilian } \\
\text { friends }\end{array}$} & \multirow[b]{2}{*}{ T-test } \\
\hline & Mean & $\begin{array}{l}\text { Standard } \\
\text { deviation }\end{array}$ & Mean & $\begin{array}{l}\text { Standard } \\
\text { deviation }\end{array}$ & \\
\hline $\begin{array}{l}\text { General aspects of Brazil: } \\
\text { people and products }\end{array}$ & 3.29 & 0.502 & 3.19 & 0.409 & 0.100 \\
\hline Emotional response & 4.03 & 0.777 & 3.73 & 0.661 & $0.002^{*}$ \\
\hline Arts-related attitudes & 3.81 & 0.876 & 3.68 & 0.743 & 0.212 \\
\hline Marketing aspects & 3.00 & 0.810 & 2.91 & 0.715 & 0.400 \\
\hline $\begin{array}{l}\text { Importance in the global } \\
\text { scenario }\end{array}$ & 3.64 & 0.736 & 3.43 & 0.631 & $0.026^{*}$ \\
\hline
\end{tabular}

Source: Authors' calculations based on survey data

* The t-test showed statistically significant differences for a range of $95 \%$ confidence. 
However, there was a difference in the analysis of country image among different levels of education for all latent variables, except for marketing aspects (Table $3)$. In general, the higher the level of education, the better the evaluation of Brazil's image.

Table 3: Difference between groups in country image evaluation

\begin{tabular}{|c|c|c|c|c|c|c|}
\hline \multirow[b]{2}{*}{ Latent variables } & \multicolumn{2}{|c|}{$\begin{array}{c}\text { No graduate } \\
\text { degree }\end{array}$} & \multicolumn{2}{|c|}{ Undergraduate } & \multicolumn{2}{|c|}{ Graduate } \\
\hline & Mean & $\begin{array}{l}\text { Standard } \\
\text { deviation }\end{array}$ & Mean & $\begin{array}{l}\text { Standard } \\
\text { deviation }\end{array}$ & Mean & $\begin{array}{l}\text { Standaro } \\
\text { deviation }\end{array}$ \\
\hline $\begin{array}{l}\text { General aspects of } \\
\text { Brazil: people and } \\
\text { products }\end{array}$ & 3.11 & 0.453 & 3.20 & 0.448 & 3.29 & 0.405 \\
\hline Emotional response & 3.60 & 0.795 & 3.79 & 0.700 & 3.96 & 0.660 \\
\hline Arts-related attitudes & 3.45 & 0.858 & 3.68 & 0.764 & 3.89 & 0.760 \\
\hline Marketing aspects*** & 2.83 & 0.717 & 2.96 & 0.764 & 2.90 & 0.723 \\
\hline $\begin{array}{l}\text { Importance in the } \\
\text { global scenario }\end{array}$ & 3.25 & 0.647 & 3.48 & 0.678 & 3.62 & 0.643 \\
\hline
\end{tabular}

Source: Authors' calculations based on survey data

* The t-test showed no statistically significant differences for a range of $95 \%$ confidence.

There was no significant difference between genders, although women, on average, make better assessments of country image dimensions (except for Brazil's importance in the global scenario). Likewise, marital status showed no significant differences between the groups, although, on average, married respondents view the image dimensions of Brazil more positively.

\subsection{Why do such differences exist?}

After differences between groups were found, especially among respondents who have visited Brazil and the others, as well as between groups with different levels of education, the third question of this study was analyzed: Why do these differences exist? Thus, a theoretical basis was sought in the literature to justify the difference in the assessment.

First, it should be noted that the stereotypes of a country comprise a series of beliefs about the landscape, culture and economy of that country. These beliefs form a complex mental structure, which allows consumers to make inferences about the attributes of products, i.e., an initial assessment of their performance (VERLEGH et al., 1999). In this case, the beliefs of the respondents who did not visit Brazil are the result of their knowledge and stereotypes disseminated through the media. These stereotypical beliefs can change according to respondents' experiences (the visit itself), especially if they are positive. 
However, the recent economic and financial crisis in Europe (and other developed countries), threatens the strength of relations between economically "weak" and "strong" nations, renewing the sense of nationalism - which can influence the feelings of ethnocentrism and animosity (antipathy remains related to political or economic events - Klein et al., 1998) of consumers (DE NISCO et al., 2013), affecting the evaluation of Brazil's image. That is, there is a mental promotion of products and image of the country of origin of respondents.

Similarly, consumers seek to preserve or improve their self-images with the purchase of products that they consider in line with such self-images, and avoid buying or evaluating products that are not consistent with them (SCHIFFMAN; KANUK, 1997). Thus, Brazilian products may somehow fail to represent the self-images of foreigners.

Furthermore, country image analyses require an assessment of respondents' degree of knowledge of a given country. One cannot assume that people know the degree of development of any other country (CAI, 2002). Therefore, the greater the knowledge (that is, level of education), the greater the individual's ability to compare the attributes of products and rate them. In addition, they are usually more updated and informed. Thus, the level of knowledge is indirectly associated with evaluation bias; if the level is high, the bias is reduced (BIAN; MOUTINHO, 2011).

Finally, the image that people have of certain countries directly influences the purchasing process. That is, consumers, based on their preconceptions, make an image that determines the importance or lack of importance of a certain product or brand in the market. They mentally develop a positive or undesirably negative communication composite, interfering with the performance that can change over time. (TONI; SCHULER, 2007)

\section{Conclusions}

This study advances two central research questions about Brazil's country image. The first is an analysis of the perception of Brazil's image after the pinnacle of BRICs. It is found that the image of Brazilian products cannot be considered a competitive advantage (except for typical products such as coffee, cachaça, etc.). Because of product evaluation, companies do not receive very positive reviews in the various dimensions, except for companies that have overcome the country's negative image and emerged as major global players, such as Embraer, Havaianas, Natura and Novex. These results do not differ significantly from those found by Giraldi in 2005, when there was no big inference about BRICs yet.

The second issue is about the emotional response of respondents of both study samples to Brazil, especially by respondents who have visited the country. It was found that foreigners who have visited Brazil have created an emotional bond and have a more positive image of it. Similarly, respondents with higher levels of educational attainment also have a more positive image of Brazil.

However, Brazil still has a negative image, a situation that does not seem to have improved over the years, contrary to previous studies (MARIUTTI; GIRALDI, 2012). A possible sign of change to such image, probably the result of BRIC, is that foreigners see Brazil as an emerging market which growth potential. 
Based on these results, it is suggested that marketing managers of companies operating in foreign markets should not underestimate the importance of images associated with country of origin. Nevertheless, the results raise an important issue, which refers to products and brands with positive stereotypes, such as the typical Brazilian products. It is up to the international market to explore this niche market.

The findings raise new questions. What are the key factors that influence the perception of foreigners? Are products that cater for the niche market of people with higher levels of education more efficient overseas? Similarly, are products targeted at women more efficient in the international market? Is there an efficient way to change foreigners' stereotyped beliefs and sense of nationalism? These issues raise possibilities of researching and understanding country image and the country-of-origin effect as well as its impact on consumer behavior, marketing strategies and brand equity.

The main limitation of this paper is the sample, because it is not possible to determine how representative of the population of foreigners this sample is. Nevertheless, suggestions for further research include efforts to supplement this analysis in similar samples.

In short, researchers and marketing managers, as already warned by ZeugnerRoth and Diamantopoulos (2010), should not ignore the importance of country image, or dismiss it as non-relevant for product acceptance in the international market.

\section{References}

AGBONIFOH, B.A.; ELIMIMIAN, J.U. Attitudes of developing countries towards "country-of-origin" products in an era of multiple brands. Journal of International Consumer Marketing, New York, v.11, n.4, p. 97-116, 1999.

ALMEIDA, P. R. O Brasil no novo cenário global: Transformações do jogo diplomático contemporâneo. Revista Intellector, v.5, n.9, p. 1-32, 2008.

ALMEIDA, F.C.; DROUVOT, H. O Efeito do País de Origem de Produtos na Percepção de Executivos franceses e brasileiros. Gestão \& Regionalidade, v.25, n.73, p. 48-68, 2009.

ARMIJO, L. E. The Brics countries (Brazil, Russia, India, and China) as analytical category: mirage or Insight? Asian Perspective, v.31, n.4, p. 7-42, 2007.

BALABANIS, G.; MUELLER, R.; MELEWAR, T.C. Country of origin images around the World: can value priorities predict them? In: EMAC Conference, 28, Berlim, Anais... Berlin, Germany: Host: Humboldt University, 1999.

BARBÉ, E. Multilateralismo: Adaptación a un mundo con Potencias Emergentes. Revista de Desenvolvimento e Inovação, v.67, n.2, p. 21-50, 2010.

BAUMANN, R. O Brasil e os Demais BRICs: Comércio e Política. Brasília: CEPAL, 2010. 
BIAN, X.; MOUTINHO, L. The role of brand image, product involvement, and knowledge in explaining consumer purchase behaviour of counterfeits: Direct and indirect effects. European Journal of Marketing, v.45, n.1-2, p. 191-216, 2011.

BLOOMBERG. Goldman's BRIC Era Ends as Fund Folds After Years of Losses (09/11/2015). Available on: http://www.bloomberg.com/news/articles/2015-1108/goldman-s-bric-era-ends-as-fund-closes-after-years-of-losses. Acessed: jan./2016.

CAI, Y. Country-of-origin effects on consumers' willingness to buy foreign products: an experiment in consumer decision making. Master (thesis) - Graduate Faculty of The University of Georgia NanKai University, China, 2002.

DE NISCO, A.; MAINOLFI, G.; MARINO, V.; NAPOLITANO, M.R. The influence of consumer ethnocentrism, animosity and product country image perception on attitudes towards foreign products. A study on Italian consumers. In: GUMMESSON, E.; MELE, C.; POLESE, F. (Eds.) Service Dominant Logic, Network and Systems Theory and Service Science: Integrating three Perspectives for a New Service Agenda. Giannini, Napoli, 2013.

FLICK, U. Desenho da pesquisa qualitativa. Porto Alegre: Artmed, 2009.

FONSECA Jr., G. BRICS: notas e questões. In: PIMENTEL, J.V.S.; RICUPERO, R.; AMARAL, S. (org.). O Brasil, os BRICS e a agenda internacional. Brasília: FINAG, 2012.

GAEDAKE, R. Consumer attitudes toward products "made in" developing countries. Journal of Retailing, v.49, n.2, p. 13-24, 1973.

GHOSHAL, S.; TANURE, B. Estratégia e gestão empresarial: construindo empresas brasileiras de sucesso: estudos de casos. Rio de Janeiro: Elsevier, 2004.

GIL, A.C. Como elaborar projetos de pesquisa. 5. ed. São Paulo: Atlas, 2010.

GIRALDI, J. M. E. A influência da imagem do Brasil na atitude de consumidores estrangeiros com relação a produtos brasileiros: um estudo com estudantes universitários holandeses. Dissertação (Mestrado), Universidade de São Paulo, São Paulo-SP, 2005.

GIRALDI, J.M.E.; CARVALHO, D.T. Imagem de países: uma investigação empírica sobre as dimensões da imagem do Brasil. Revista de Economia e Administração, v.5, n.40, p. 497-515, 2006.

GIRALDI, J.M.E.; IKEDA, A.K. Uma Aplicação da Abordagem de Personificação no Estudo de Imagem de País. Brazilian Business Review, v.6, n.2, p. 137-153, 2009.

GIRALDI, J. M. E.; NETO, A. J. M. Efeito País de Origem para Calçados brasileiros. Alcance, n.15, v.1, p.23-41, 2008.

GIRALDI, J.M.E.; TORNAVOI, C.D.A. O uso da informação sobre o país de origem como fonte de vantagem competitiva nos mercados externos. Revista de Administração Mackenzie, São Paulo, v.6, n.1, p.129-156, 2005. 
GUILHOTO, L. A Influência do País de Origem na percepção do consumidor sobre a qualidade dos produtos. Caderno de Pesquisas em Administração, São Paulo, v.8, n.4, p.53-64, 2001.

HAIR, J. F.; ANDERSON, R. E.; TATHAM, R. L.; BLACK, W. C. Análise multivariada de dados. 5 ed. Porto Alegre: Bookman, 2005.

HAN, M. Country image: halo or summary construct? Journal of Marketing Research, v.26, n.2, p. 222-229, 1989.

HURRELL, A. Hegemony, liberalism and global order. International Affairs, v.82, n.1, p. 1-20, 2006.

IKENBERRY, J.G.; WRIGHT, T. Rising powers and global institutions. New York: The Century Foundation, 2008.

JAFFE, E.D.; NEBENZHAL, I.D. National image and Competitive Advantage: The Theory and Practice of Place Branding. $2^{a}$ ed. Copenhagen Business School Press, 2006.

JOHANSSON, J.K.; DOUGLAS, S.P.; NONAKA, I. Assessing the Impact of Country of Origin on Product Evaluations: A New Methodological Perspective. Journal of Marketing Research, v.22, p. 388-396, 1985.

KLEIN J.G.; ETTENSON R.; MORRIS M.D. The animosity model of foreign product purchase: an empirical test in the People's Republic of China. Journal of Marketing, v.62, p.89-100, 1998.

KOTLER, P.; GERTNER, D. Marca-país: ativo estratégico para alavancar o crescimento. HSM Management, São Paulo, v.3, n.44, p.61-65, 2004.

MALHOTRA, N. K. Pesquisa de marketing: uma orientação aplicada. 4. ed. São Paulo: Bookman, 2006.

MARIUTTI, F.G.; GIRALDI, J.M.E. Análise da Imagem do Brasil por meio do Anholt Nation Branding Index. Revista Turismo Visão e Ação, v.14, n.1, p. 67-81, Jan/Abr. 2012.

MONTEALEGRE, O. Breaking apart: the end of 'BRIC' (2013). Available on: http://www.diplomaticourier.com/news/regions/brics/1475-breaking-apart-the-end-ofbric. Accessed: nov./2015.

MORGAN, N.; PRITCHARD, A.; PIGGOTT, R. New Zealand, 100\% Pure. The creation of a powerful niche destination brand. Journal of Brand Management, v.9, n.4/5, p. 335, 2002.

NARLIKAR, A. Negotiating the rise of new powers. International Affairs, v.89, n.3, p. 561-576, 2013. 
NEBENZAHL, I. D.; JAFFE, D.; USUNIER, J. C. Personifying country of origin research. Management International Review, Wiesbaden, v.43, n.4, p. 383-406, 2006.

NOGUEIRA, J.P. Os BRICS e as transformações na ordem mundial. Rio de Janeiro: PUC-Rio, 2012.

O'NEILL, J. Building Better Global Economic BRICs (2001). Available on: http://www.goldmansachs.com/our-thinking/archive/archive-pdfs/build-better-brics.pdf Accessed: oct./2015.

PESSOA, J. F. R.; AYROSA, E. A. T. Imagem de País de Origem e Atitude em Relação a Filmes de Origens Diversas: A Influência do Afeto, Cognição e Comportamento. In: Encontro de Marketing da Anpad (EMA), 4, Florianópolis, Anais... ANPAD, Florianópolis, 2010.

ROCHA, A.; MELLO, R. C. Como e quando usar o selo Made in Brazil. (2011). Available on: http://www.biblioteca.sebrae.com.br/bds/bds.nsf/E34628446267CBB0832578460082 F12A/\$File/NT00045402.pdf. Accessed: oct./2015.

SCHIFFMAN, L.G.; KANUK, L.L. Consumer Behavior. [S.I.]: Prentice Hall, 1997.

THORSTENSEN, V.; OLIVEIRA, I. Os BRICS na OMC: políticas comerciais comparadas de Brasil, Rússia, Índia e África do Sul. Brasília, IPEA, 2012;

TONI, D.; SCHULER, M. Gestão da Imagem: Desenvolvendo um Instrumento para a Configuração da Imagem de Produto. Revista de Administração Contemporânea, v.11, n. 4, p. 131-151, Out./Dez. 2007.

ULGADO, F.; LEE, M. The Korean versus American marketplace: Consumer reactions to foreign products. Psychology and Marketing, v.15, n.6, p. 595-614, 1998.

VERLEGH, P.W.J.; ALTHUIJZEN, N.A.P.; VROEGH, T.P. Country stereotypes: cognition, affect and product judgment. In: EMAC Conference, 28, Berlim, Anais... Berlin, Germany: Host: Humboldt University, 1999.

VIVERO, J. L. S.; MATEOS, J. C. R. Ocean governance in a competitive world. The BRIC countries as emerging maritime powers - building new geopolitical scenarios. Marine Policy, v.34, p. 967-978, 2010.

WANG, C.; LAMB, C. The impact of selected environmental forces upon consumers' willingness to buy foreign products. Journal of the Academy of Marketing Science, Greenvale, v. 11, n.1, p. 71-84, 1983.

WHITE, P.D.; CUNDIFF, E.W. Assessing the Quality of Industrial Products. Journal of Marketing, v. 42, n.1, p.80-86, 1978. 